\title{
PENERAPAN KOLABORASI STRATEGI METAKOGNITIF DALAM MENINGKATKAN HASIL BELAJAR SISWA PADA MATERI MENULIS KARYA ILMIAH
}

\author{
Bayu Dwi Nurwicaksono \\ Politeknik Negeri Media Kreatif Jakarta \\ e-mail: bayu.poltek.media@gmail.com
}

\begin{abstract}
Abstrak: Penelitian ini dilatarbelakangi oleh rendahnya akumulasi nilai kognitif, afektif, dan psikomotorik siswa dalam pembelajaran menulis karya ilmiah, yakni 63,45. Padahal berdasarkan tes awal, siswa memiliki potensi dalam pengembangan intelektual. Tujuan penelitian ini adalah untuk mendeskripsikan hasil belajar siswa pada materi menulis karya ilmiah dengan menerapkan kolaborasi strategi metakognitif. Penelitian tindakan kelas ini merupakan penelitian deskriptif kuantitatif. Subjek penelitiannya ialah siswa kelas XI IPA-2 SMA Trisila Surabaya. Instrumen yang digunakan ialah tes dan nontes. Hasil penelitian menunjukkan hasil belajar siswa mengalami peningkatan signifikan dari nilai akhir rata-rata siswa pada siklus 1 yang mencapai 72,97 dengan jumlah siswa yang telah tuntas belajar sebanyak $82,05 \%$ ke nilai akhir rata-rata siswa pada siklus 2 yang mencapai 87,07 dengan jumlah siswa telah tuntas belajar sebanyak $100 \%$. Oleh karena itu, strategi kolaborasi metakognitif ini disarankan dapat digunakan guru dalam pembelajaran menulis karya ilmiah.
\end{abstract}

Kata kunci: strategi metakognitif, menulis karya ilmiah, hasil belajar

\begin{abstract}
This research is motivated by the low accumulation of cognitive, affective, and psychomotor values of students in scientific writing, that's 63.45 . Whereas based on preliminary tests, students have potential in intellectual development. The purpose of this study is to describe student learning outcomes on the materials of writing scientific papers by applying metacognitive strategy collaboration. This classroom action research is a quantitative descriptive study. The subject of his research is the students of class XI.IPA.2 SMA Trisila Surabaya. The instruments used are tests and not test. The result of the research showed that the students' learning achievement significantly improved from the average score of the students on the first cycle which reached 72.97 with the total number of students who have completed the study as much as $82.05 \%$ to the final grade of the students on cycle 2 reaching 87.07 with the number of students have completed learning $100 \%$. Therefore, this metacognitive collaboration strategy is suggested to be used in the learning of writing scientific papers.
\end{abstract}

Keywords: metacognitive strategies, writing scientific papers, learning outcomes

\section{PENDAHULUAN}

Menulis merupakan kegiatan yang memberdayakan diri karena ketika seseorang menulis terjadi proses berpikir dalam rangka mengeluarkan ide dan pemikiran. Agar ide dapat tersampaikan dengan baik kepada pembaca maka diperlukan kemampuan menulis yang baik. Siswa merupakan subjek belajar tentang berbagai ilmu pengetahuan. Sebagai intelektual muda, siswa perlu dibiasakan membaca dan menulis tentang berbagai pengetahuan ilmiah karena kebiasaan tersebut dapat memberdayakan siswa.

Standar kompetensi mata pelajaran bahasa Indonesia bertujuan agar siswa terbuka terhadap beraneka ragam informasi yang hadir di sekitar siswa dan dapat menyaring informasi yang 
berguna, belajar menjadi diri sendiri, dan siswa menyadari eksistensi budayanya sehingga tidak melupakan lingkungannya. Dengan standar kompetensi mata pelajaran bahasa Indonesia ini diharapkan (1) siswa dapat mengembangkan potensinya sesuai dengan kemampuan, kebutuhan, dan minatnya, serta dapat menumbuhkan penghargaan terhadap hasil karya intelektual bangsa sendiri; (2) guru dapat memusatkan perhatian kepada pengembangan kompetensi bahasa siswa dengan menyediakan berbagai kegiatan berbahasa dan sumber belajar; (3) guru lebih mandiri dan leluasa dalam menentukan bahan ajar kebahasaan sesuai dengan kondisi lingkungan sekolah dan kemampuan siswa.

Salah satu indikator ketercapaian keterampilan menulis pada siswa kelas XI semester genap adalah menulis karya ilmiah seperti hasil pengamatan dan penelitian. Dalam penelitian ini, pembelajaran keterampilan menulis difokuskan pada pembelajaran menulis karya ilmiah. Fokus pokok pembelajaran tersebut didasarkan pada permasalahan yang terjadi di SMA Trisila Surabaya pada umumnya dan di kelas XI IPA-2 pada khususnya.

Berdasarkan hasil wawancara dengan guru bahasa Indonesia SMA Trisila Surabaya pada 2 Desember 2008 dan 26 Januari 2009 diketahui bahwa siswa kelas XI IPA-2 tahun pelajaran 2008-2009 merupakan siswa yang berpotensi dalam pengembangan intelektual dan memiliki ketekunan yang tinggi. Namun demikian ratarata nilai akhir hasil akumulasi penilaian kognitif, afektif, dan psikomotorik masih di bawah KKM, yakni 63,45. Karena itu, penelitian tindakan kelas ini akan diterapkan di kelas XI IPA-2 dengan cara menerapkan kolaborasi strategi metakognitif dalam menulis karya ilmiah.

Keterampilan menulis diajarkan dengan tujuan agar siswa mempunyai kemampuan dalam menuangkan ide, gagasan, pikiran, pengalaman, dan pendapatnya dengan benar. Sebelum kegiatan menulis berlangsung, seseorang perlu membuat perencanaan, misalnya: menyeleksi topik, menata, dan mengorganisasikan gagasan serta mempertimbangkan bentuk tulisan disesuaikan dengan sasaran pembacanya. Pada saat menuangkan ide, penulis harus menyajikan gagasannya secara teratur. Begitu pula penggunaan aspek kebahasaan seperti bentukan kata, diksi, dan kalimat harus disusun secara efektif. Penerapan ejaan dan tanda baca pun harus dilakukan secara tepat dan fungsional. Sejumlah keterampilan tersebut menjadi bukti bahwa pembelajaran menulis merupakan pembelajaran yang kompleks sekaligus menunjukkan bahwa seseorang memerlukan tiga keterampilan berbahasa yang lain, yakni membaca, menyimak, dan berbicara bila ingin menulis karya ilmiah dengan baik.

Tahap-tahap menulis oleh Akhadiah (1996: 3-5) terdiri atas tiga tahap, yakni tahap prapenulisan, penulisan, dan revisi. Tahap prapenulisan merupakan tahap perencanaan atau persiapan menulis dan mencakup beberapa langkah kegiatan, yaitu (1) menentukan topik, (2) membatasi topik, (3) menentukan bahan, (4) menyusun kerangka karangan. Pada tahap penulisan, dibahas setiap butir topik yang ada di dalam kerangka karangan dan secara otomatis menggunakan bahan-bahan yang sudah diperoleh. Setelah seluruh tulisan selesai, tulisan tersebut memerlukan penyuntingan (revisi). Mungkin perlu menambahkan, mengurangkan, atau bahkan menyisipkan ide baru untuk melengkapi tulisan tersebut.

Menurut Purwanto (2007:5-6), tujuan dan kegunaan menulis karya ilmiah, yaitu (1) sebagai wahana melatih dan mengungkapkan pemikiran atau hasil pengamatan siswa dalam bentuk tulisan ilmiah yang sistematis dan metodologis; (2) untuk menumbuhkan etos ilmiah di kalangan siswa, 
sehingga tidak hanya menjadi konsumen ilmu pengetahuan, tetapi juga mampu menjadi penghasil (produsen) pemikiran dan karya tulis dalam bidang ilmu pengetahuan; (3) sebagai wahana transformasi pengetahuan dari sekolah ke masyarakat, atau orang-orang yang berminat membacanya; (4) untuk membuktikan potensi dan wawasan ilmiah yang dimiliki siswa dalam menghadapi dan menyelesaikan masalah dalam bentuk karya ilmiah setelah yang bersangkutan memperoleh pengetahuan dan pendidikan; (5) untuk melatih keterampilan dasar dalam melakukan penelitian dan atau pengamatan.

Kelima kegunaan tersebut akan mempersiapkan dan membiasakan siswa berpikir secara logis dan sistematis sejak mengenyam bangku pendidikan. Dengan demikian tujuan dan kegunaan menulis karya ilmiah ini adalah mengantarkan manusia Indonesia yang beradab dengan memanfaatkan pikirannya secara optimal.

Strategi pembelajaran adalah komponen yang sangat menentukan dalam pencapaian tujuan pembelajaran. Oleh karena itu, setiap guru perlu memahami secara baik peran dan fungsi strategi dalam pelaksanaan proses pembelajaran. Strategi-strategi yang selaras dengan sistem pembelajaran berbasis otak (brain based teaching) di antaranya adalah strategi metakognitif, strategi kognitif, dan strategi afektif.

Strategi metakognitif mencakup (1) advance organization (memajukan organisasi), yang berarti tinjauan pendahuluan terhadap ide-ide utama dan konsep-konsep bahan yang akan dipelajari; (2) advance preparation (meningkatkan persiapan), yang berarti latihan bahasa yang diperlukan bagi tugas lisan atau tertulis; (3) organizational planning (perencanaan organisasional), yang berarti merencanakan bagian-bagian, urutan, dan ide-ide pokok yang akan diekspresikan secara lisan atau dalam tulisan; (4) selective attention (perhatian selektif), yang berarti mengikuti atau membaca sekilas kata-kata kunci, frasa-frasa pemarkah-pemarkah linguistik, kalimat-kalimat, atau tipe-tipe informasi; (5) self-monitoring (swapantau), yang berarti mengecek pemahaman seseorang selama menyimak atau membaca, produksi lisan atau tulis; (6) self-evaluation (swa-nilai), yang berarti menilai seberapa baik seseorang menyelesaikan suatu tugas pembelajaran; (7) self-management (swa-kelola), yang berarti mencari atau menata kondisi-kondisi yang membantu seseorang belajar, misalnya menemukan kesempatan buat tambahan input dan latihan bahasa dan isi.

Strategi kognitif meliputi (1) resourcing (pencarian sumber), yang berarti penggunaan bahan-bahan acuan seperti kamus, ensiklopedi, atau buku teks; (2) grouping (pengelompokan), yang berarti pengklasifikasian kata-kata, istilahistilah, jumlah, atau konsep-konsep; (3) note taking (pembuatan catatan), yang berarti mencatat kata-kata kunci atau konsep-konsep penting secara singkat; (4) summarizing (perangkuman), yang berarti membuat rangkuman mental atau tertulis dari bacaan atau simakan; (5) deduction (deduksi), yang berarti penggunaan kaidah-kaidah untuk memahami atau memproduksi bahasa atau memecahkan masalah; (6) imagery (imajeri), yang berarti penggunaan imaji-imaji visual untuk memahami atau mengingat informasi baru; (7) auditory representation (representasi auditori), yang berarti mengucapkan atau meniru dalam hati bunyi kata atau frasa untuk membantu pemahaman atau ingatan; (8) elaboration (perluasan), yang berarti penghubungan informasi baru dengan pengetahuan terdahulu dan menghubungkan bagian-bagian satu sama lainnya; (9) transfer (pemindahan), yang berarti penggunaan apa-apa yang telah diketahui mengenai bahasa untuk membantu pemahaman; (10) inferencing 
(penyimpulan), yang berarti penggunaan informasi dalam teks untuk menebak makna butirbutir baru atau mengisi bagian-bagian yang hilang.

Strategi-strategi afektif meliputi (1) questioning for clarification, yang berarti memperoleh penjelasan tambahan dari pengajar atau teman sekelas; (2) cooperation, yang berarti bekerjasama dengan teman-teman sekelas memecahkan suatu masalah dan mengumpulkan informasi; (3) self-talk, yang berarti mengurangi kecemasan dengan menggunakan teknik-teknik mental yang membuat seseorang merasa mampu melaksanakan tugas pembelajaran.

\section{METODE}

Penelitian ini menggunakan rancangan penelitian deskriptif kuantitatif. Hal tersebut sesuai dengan pendapat Moleong (2005:3), termasuk penelitian deskriptif kuantitatif karena data yang dihasilkan juga berupa angka-angka pada hasil belajar siswa. Berdasarkan tujuan penelitian ini yang berupaya meningkatkan kualitas pembelajaran, maka penelitian ini termasuk penelitian tindakan kelas. Hal itu sesuai dengan pendapat Kemmis (dalam Ardiana dan Laksono, 2003:5), penelitian tindakan kelas adalah suatu bentuk kegiatan yang bersifat reflektif, tindakan yang dilakukan dalam rangka melaksanakan tugas, memperdalam pemahaman terhadap tindakan yang dilakukan serta perbaikan terhadap tempat praktik akan dilakukan. Bentuk instrumen yang digunakan dalam penelitian ini adalah tes dan nontes. Tes yang digunakan dalam penelitian ini adalah lembar soal untuk mengukur pencapaian seseorang setelah mempelajari materi sedangkan instrumen dalam bentuk nontes dalam penelitian ini adalah observasi. Observasi dilakukan dengan menggunakan lembar pengamatan proses dan produk (Arikunto, 2006:150-151).

\section{HASIL DAN KESIMPULAN}

Hasil belajar siswa dalam pembelajaran menulis karya ilmiah ini diambil dari tiga aspek penilaian, yaitu penilaian proses, penilaian produk, dan tes hasil evaluasi. Ketiga penilaian ini pada akhirnya dijumlahkan dan dirata-rata. Berikut disajikan penilaian proses, penilaian produk, dan tes evaluasi pada setiap siklus. Siklus 1 ini dilaksanakan dalam empat kali pertemuan di SMA Trisila Surabaya. Setiap pertemuan berdurasi 2 x 45 menit. Butir siklus 1 ini diuraikan menjadi tiga butir, yakni penilaian proses, penilaian produk, dan tes.

Dalam penilaian proses, lembar observasi guru digunakan untuk mengumpulkan data tentang aspek afektif yang terjadi pada diri siswa, partisipasi siswa dalam pembelajaran, sikap khusus, dan respons siswa baik dalam kegiatan membaca, menyimak, berbicara, maupun menulis, khususnya menulis karya ilmiah. Karena itu, empat aspek afektif yang dinilai adalah (a) kerjasama, (b) keaktifan atau ketekunan, (c) keterbukaan terhadap kritik, dan (d) kemauan memperbaiki hasil kerja. Berikut ini data hasil penilaian proses siswa kelas XI IPA-2 yang berjumlah 39 orang pada siklus 1 .

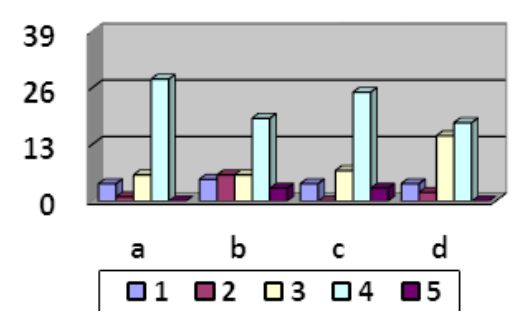

Grafik 1. Penilaian Proses Siklus 1

Keterangan:

Skor 1: Sangat kurang

Skor 2: kurang

Skor 3: cukup

Skor 4: baik

Skor 5: baik sekali

Siswa yang mempunyai kecerdasan afektif akan aktif sekali mengikuti pembelajaran, 
bahkan di luar jam pelajaran pun siswa antusias terhadap pembelajaran dan pengembangan diri. Hal ini terjadi karena siswa memiliki kekuatan emosi atau hasrat yang kuat untuk mencapai tujuan tertentu. Namun jika kecerdasan afektif itu belum terbentuk secara kokoh maka siswa cenderung menghindar dan menjauhi pembelajaran karya ilmiah dengan bermalas-malasan.

Aspek kognitif merupakan aspek yang mengeksplorasi kemampuan siswa menerima, mengolah, dan membangun pemikiran pun berpengaruh terhadap keaktifan dan ketekunan siswa. Siswa yang memiliki kecerdasan kognitif baik cenderung aktif dan aktif sekali. Hal ini disebabkan pengetahuan siswa yang luas, sehingga ketika guru memberikan pertanyaan dan mempersilakan bertanya, siswa yang mempunyai pengetahuan luaslah yang memberikan respons, karena terdapat sejumlah pengetahuan terdahulunya yang relevan dengan pengetahuan yang baru didapatnya. Sebaliknya jika kecerdasan kognitif siswa masuk kategori sangat kurang atau kurang, maka siswa cenderung tidak aktif karena pengetahuan yang baru didapatnya tidak memiliki sambungan dengan pengetahuan sebelumnya.

Aspek psikomotorik merupakan aspek yang memberdayakan fisik untuk menjalankan dan menyelesaikan tugas-tugas dengan melakukan sejumlah tindakan. Aspek keaktifan dan ketekunan ini memerlukan kecerdasan psikomotorik yang baik agar dapat berjalan dengan maksimal. Dalam pembelajaran karya ilmiah ini pun demikian, faktor kesehatan baik guru maupun siswa berpengaruh terhadap optimalisasi pembelajaran.

Konteks kemauan memperbaiki hasil kerja ini dalam aspek afeksi adalah kesadaran siswa terhadap pentingnya revisi hasil kerja. Sementara itu, konteks kemauan memperbaiki hasil kerja dalam aspek psikomotorik ialah tindakan dan gerakan fisik secara nyata yang dilakukan siswa dalam memperbaiki hasil kerjanya seusai men- dapatkan masukan, saran, dan kritik dari guru atau siswa lain. Penilaian aspek kemauan memperbaiki hasil belajar dalam pembelajaran menulis karya ilmiah ini dinyatakan sehat apabila tidak terdapat lagi siswa yang sangat kurang atau kurang bersedia memperbaiki hasil kerja.

Penilaian produk diambil dari lima kriteria, yakni (1) pemilihan judul yang sesuai dengan tema dan unik; (2) pengembangan ide yang sesuai dengan tema dan disertai penjelasan rinci dan akurat; (3) pengorganisasian informasi dan ide yang disajikan secara logis; (4) pengungkapan bukti-bukti yang menarik dan memiliki konsistensi isi dalam keseluruhan tulisan yang runtut; (5) Penggunaan bahasa yang bebas dari kesalahan penggunaan kata dan struktur kalimat. Data hasil penilaian produk pada siklus 1 terlihat pada grafik berikut.

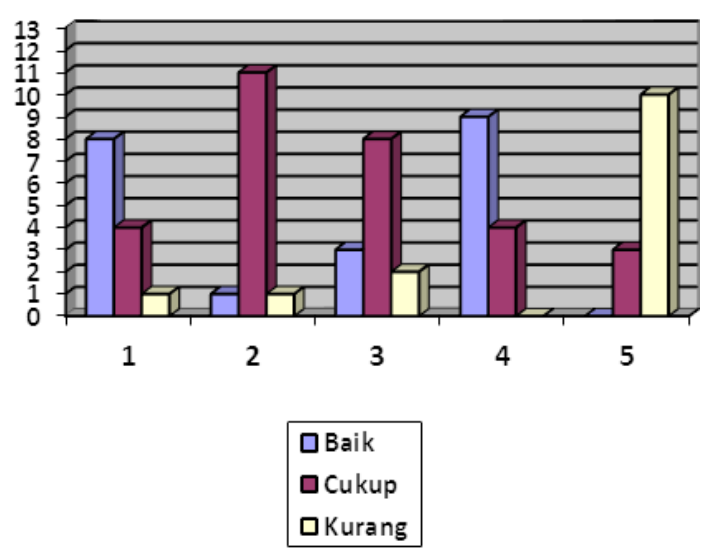

Grafik 2. Hasil Penilaian Produk Siklus 1

Dalam pembelajaran karya ilmiah ini mayoritas siswa dapat menentukan judul karya ilmiah dengan baik. Hal itu merupakan hasil kerja keras siswa dalam mengikuti pembelajaran menulis karya ilmiah dengan menerapkan brain based learning. Dalam hal ini, tahapan pembelajaran yang berperan dalam membantu siswa menentukan judul penelitian adalah tahap cooperation, grouping, note taking, summarizing, dan deduction. Dalam tahap tersebut, siswa berdis- 
kusi dan bertukar pengalaman serta pengetahuannya saat membaca sumber referensi yang terkait dengan topik karya ilmiah yang ada. Jadi judul penelitian tersebut merupakan hasil pemikiran dan kristalisasi pengetahuan siswa.

Tes evaluasi dalam pembelajaran karya ilmiah siklus 1 ini terdapat dua bentuk, yakni bentuk tes esai dan tes objektif. Tes esai dalam pembelajaran karya ilmiah ini menuntut jawaban siswa dalam bentuk uraian yang menggunakan bahasa sendiri. Tuckman dalam Nurgiyantoro (1998:68) menyatakan bahwa dalam tes bentuk esai siswa dituntut berpikir tentang dan menggunakan apa yang diketahui yang berkenaan dengan pertanyaan yang harus dijawab dan memberikan kebebasan kepada siswa untuk menyusun dan mengemukakan jawabannya sendiri. Pernyataan Tuckman ini sesuai dengan tujuan tes evaluasi dalam pembelajaran karya ilmiah ini, yaitu mengeksplorasi jawaban siswa berdasarkan pemahamannya menanggapi pertanyaan pada tes evaluasi dan memberikan kebebasan siswa dalam mengungkapkan perasaan dan mengevaluasi diri selama pembelajaran.

Selain itu dalam tes evaluasi ini juga terdapat soal bentuk objektif, yakni soal yang menuntut siswa memberikan jawaban singkat dengan memilih kode-kode tertentu yang mewakili alternatif-alternatif jawaban yang telah disediakan. Pada tes evaluasi siklus 1 ini terdapat 5 buah soal objektif. Berikut ini hasil penilaian tes evaluasi siklus 1.

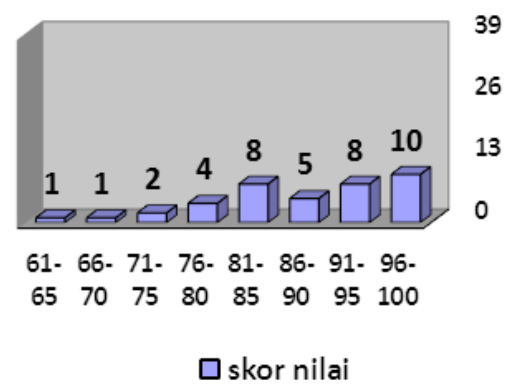

Grafik 3. Penilaian Tes Evaluasi Siklus 1
Grafik perolehan skor nilai di atas menunjukkan tren positif, yakni nilai kategori baik dan baik sekali mendominasi di kelas XI IPA-2 ini. Kondisi sebaliknya yakni nilai kategori cukup dan cukup baik diperoleh sebagian kecil siswa. Pada siklus berikutnya diharapkan siswa yang saat ini berada di posisi kategori cukup dan cukup baik dapat berpindah posisi di kategori baik dan baik sekali sehingga tren perolehan skor tes evaluasi terus bergerak positif.

Siklus 2 ini dilaksanakan dalam empat kali pertemuan di SMA Trisila Surabaya. Setiap pertemuan berdurasi $2 \times 45$ menit. Seperti halnya pada siklus 1, penilaian proses siklus 2 ini dilakukan berdasarkan lembar observasi siswa. Berikut ini data hasil penilaian proses siswa pada siklus 2 .

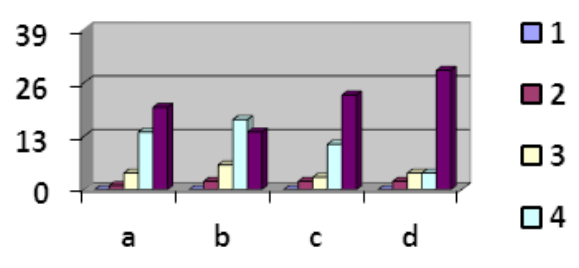

Grafik 4. Penilaian Proses Siklus 2

Skor 1: Sangat kurang

Skor 2: kurang

Skor 3: cukup

Skor 4: baik

Skor 5: baik sekali

Penilaian produk pada siklus 2 diambil dari lima kriteria, yakni (1) pemilihan judul yang sesuai dengan tema dan unik; (2) pengembangan ide yang sesuai dengan tema dan disertai penjelasan rinci, akurat; (3) pengorganisasian informasi dan ide yang disajikan secara logis; (4) pengungkapan bukti-bukti yang menarik dan memiliki konsistensi isi dalam keseluruhan tulisan, serta runtut; (5) Penggunaan bahasa yang bebas dari kesalahan penggunaan kata dan struktur kalimat. 
Data hasil penilaian produk pada siklus 2 terlihat pada grafik berikut.

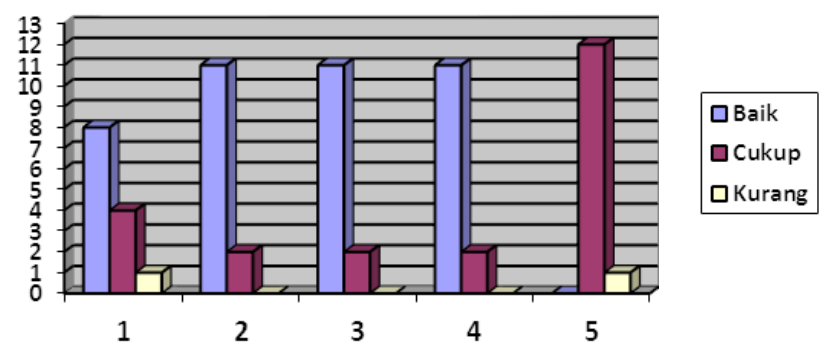

Grafik 5. Hasil Penilaian Produk Siklus 2

Seperti pada hasil belajar siklus 1, penilaian produk pada aspek pemilihan judul pada siklus 2 ini pun hasilnya sama karena produk karya ilmiah yang dihasilkan sama. Pada siklus 1 berupa proposal penelitian sedangkan siklus 2 berupa laporan hasil penelitian. Jadi penilaian mengenai aspek pemilihan judul tidak ada perubahan karena judul penelitian siswa beracuan pada proposal penelitian yang telah dibuat pada siklus 1 .

Tes evaluasi dalam pembelajaran karya ilmiah siklus 2 ini hanya terdapat satu bentuk, yakni bentuk tes esai. Tes esai dalam pembelajaran karya ilmiah ini menuntut jawaban siswa dalam bentuk uraian yang menggunakan bahasa sendiri. Masih tetap sesuai dengan pernyataan Tuckman, tujuan tes evaluasi dalam pembelajaran karya ilmiah ini, adalah mengeksplorasi jawaban siswa berdasarkan pemahamannya menanggapi pertanyaan pada tes evaluasi dan memberikan kebebasan siswa dalam mengungkapkan perasaan dan mengevaluasi diri selama pembelajaran. Berikut ini hasil penilaian tes evaluasi siklus 2 .

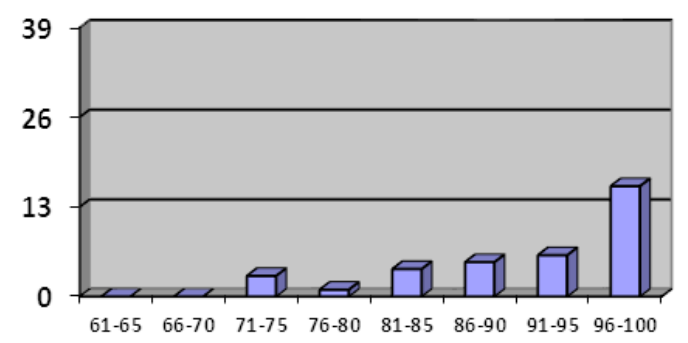

Grafik 6. Penilaian Tes Evaluasi Siklus 2
Grafik perolehan skor nilai di atas menunjukkan peningkatan, yakni semua siswa telah mencapai kriteria nilai ketuntasan minimal. Kondisi ini merupakan kemajuan dari siklus sebelumnya yang masih terdapat siswa yang memperoleh nilai di bawah KKM yakni dua siswa yang memiliki nilai 65 dan 66. Peningkatan ini menunjukkan tren perolehan skor tes evaluasi yang terus bergerak positif. Meski demikian hasil tes evaluasi ini secara personal terdapat lima siswa yang mengalami penurunan nilai. Nilai tes evaluasi siklus 2 lima siswa ini lebih rendah daripada nilai tes evaluasi siklus 1 . Namun penurunan nilai ini tidak sampai di bawah KKM bahasa Indonesia kelas XI IPA SMA Trisila. Sementara itu, nilai rata-rata akumulatif siswa kelas XI IPA 2 SMA Trisila ini seperti yang terdapat pada tabel berikut ini.

Tabel1

Nilai Rata-rata Akumulatif Siklus 1 dan 2

\begin{tabular}{|c|c|c|c|c|c|}
\hline \multirow{2}{*}{ Siklus } & \multicolumn{3}{|c|}{ Rata-rata } & \multirow{2}{*}{ Rerata } & \multirow{2}{*}{ Ketuntasan } \\
\cline { 2 - 4 } & Proses & Produk & Tes & & \\
\hline I & 67 & 64,31 & 87,61 & 72,97 & $82,05 \%$ \\
\hline II & 86 & 84 & 91,20 & 87,07 & $100 \quad \%$ \\
\hline
\end{tabular}

Dengan demikian dapat disimpulkan bahwa sistem pembelajaran berbasis otak merupakan sistem pembelajaran yang efektif digunakan dalam pembelajaran menulis karya ilmiah karena dapat meningkatkan proses dan hasil belajar siswa. Peningkatan nilai hasil belajar yang signifikan tersebut merupakan implikasi langsung dari kolaborasi strategi metakognitif, strategi kognitif, dan strategi afektif.

Pada tahap pendahuluan dalam penyusunan karya ilmiah, langkah-langkah meliputi: Advanced Organization, Advance Preparation, Self-Monitoring, Cooperation, Grouping, Note Taking, Summarizing, Deduction, Questioning for Clari- 
fication, Resourcing, Self-Evaluation. Kemudian pada tahap pengkajian pustaka, meliputi: Cooperation, Grouping, Selection Attention, Note Taking, Summarizing, Self-Evaluation, dan SelfTalk.

Pada tahap metode penelitian, meliputi Questioning for Clarification, Organization Planning, Swamanagement, Self-Monitoring, SelfEvaluation, dan Self-Talk. Pada tahap analisis dan sintesis, langkah-langkah pembelajaran meliputi Deduction, Imagery, Elaboration, Transfer, Inferencing, Auditory Representation, SelfMonitoring, Self-Evaluation, dan Self-Talk. Pada tahap penyimpulan, tahap pembelajaran meliputi Cooperation, Advance Organization, Advance Preparation, Organization Planning, Selective Attention, Self-Monitoring, Resourcing, Grouping, Note Taking, Summarizing, Deduction, Imagery, Auditory Representation, Elaboration, Transfer, Inferencing, Self-Talk, dan Self-Evaluation.

Berdasarkan penyajian dan pengkajian data hasil penelitian ini, simpulannya adalah hasil pembelajaran keterampilan menulis karya ilmiah siswa XI.IPA.2 SMA Trisila Surabaya dengan menerapkan system pembelajaran berbasis otak menunjukkan peningkatan signifikan dari nilai akhir rata-rata siswa pada siklus 1 yang mencapai 72,97 dengan jumlah siswa yang telah tuntas belajar sebanyak $82,05 \%$ ke nilai akhir rata-rata siswa pada siklus 2 yang mencapai 87,07 dengan jumlah siswa telah tuntas belajar sebanyak 100\%.

Sarannya adalah pembelajaran menulis karya ilmiah harus terintegrasi antarbidang studi sehingga siswa dapat belajar secara nyata melalui kegiatan penelitian yang sesuai dengan keinginan- nya sekaligus siswa dapat memahami dan mengaplikasikan kaidah-kaidah kebahasaan yang baik dan benar sesuai dengan ragam bahasa ilmiah.

\section{DAFTAR PUSTAKA}

Akhadiah, Sabarti, dkk. 1996. Menulis. Jakarta: Departemen Pendidikan dan Kebudayaan. Ardiana, Leo Idra dan Kisyani Laksono. 2004. Bahan Penelitian IND/2: Penelitian Tindakan Kelas. Surabaya: Departemen Pendidikan Nasional.

Arikunto, Suharsini. 2006. Prosedur Penelitian Suatu Pendekatan Praktik: Edisi Revisi VI. Jakarta: PT Rineka Cipta.

Given, Barbara K. 2007. Brain Based Teaching. Bandung: Kaifa.

Hacker, Douglas J. 2009. Handbook of Metacognition in Education. Diakses melalui www. routledgehandbooks.com/doi/104324/ 9780203876428.ch3.

Mahdavi, Mohsen. 2014. An Overview: Metacognition in Education on International Journal of Multidisciplinary and Current Research, Volume 2, June 2014. Tersedia di www.ijmcr.com.

Moleong, Lexy. 1991. Metodologi Penelitian Kualitatif. Bandung: Remaja Rosda Karya.

Nur, Mohammad. 2004. Teori-Teori Pembelajaran Kognitif. Surabaya: PSMS Unesa.

Purwanto, Edi. 2007. Panduan Penelitian dalam Penyusunan Karya Ilmiah Remaja. Lamongan: Pustaka Mandiri.

Sanjaya, Wina. 2008. Strategi Pembelajaran Berorientasi Standar Proses Pendidikan. Jakarta: Kencana. 